\title{
Social Skills and School Performance in Portuguese and Mathematics in Elementary School Students
}

\author{
Daniel Bartholomeu \\ Núcleo de Pesquisa em Saúde e Desempenho Humano do Centro Universitário Fundação \\ Instituto para o Ensino de Osasco (FIEO), Osasco, SP, Brazil \\ José Maria Montiel ${ }^{1}$ \\ Soraia Néia \\ Marjorie C. Rocha Silva \\ Programa de Pós-Graduação em Psicologia Educacional do Centro Universitário FIEO, \\ Osasco, SP, Brazil
}

\begin{abstract}
In this study, the relations between social skills and academic performance were studied. We posed associations between social skills and performance in writing and mathematics as well as between conversational skills and these two academic performance measures in girls. In boys we posed associations between assertiveness and academic performance in the two areas. Participants were 196 elementary school children from two schools in the state of São Paulo, with ages ranging 8-10 years, 52\% females were evaluated by means of the Test of Social Skills in Children and Adolescents in school situation (THAS-C) and Test of academic performance in writing and maths. The results pointed out that greater social skills tend to be achieved in later schooling years and appear to facilitate performance in different areas of academic performance. In this sense, we suggest that the behaviors are associated with specific difficulties in writing and mathematics, and that the course of these associations varies within sex and age. Furthermore, is indicated the importance of the evaluation of social skills in the academic context given the associated educational connections.
\end{abstract}

Keywords: Academic assessment, school performance, social skills.

\section{Habilidades Sociais e Desempenho Escolar em Português e Matemática em Estudantes do Ensino Fundamental}

\section{Resumo}

No presente trabalho verificou-se a relação das habilidades sociais e desempenho escolar em diferentes anos escolares e por sexo, visando fornecer evidências de validade para o Teste de Habilidades Sociais em Crianças e Adolescentes em situação escolar (THAS-C). Foram avaliadas 196 crianças do Ensino Fundamental de duas escolas do interior do estado de São Paulo, com idades que variaram de 8 a 10 anos, sendo 52\% do sexo feminino. Foi aplicado o Teste de Habilidades Sociais para crianças em situação escolar e o Teste de Desempenho de Escrita, Leitura e Matemática. Dentre os resultados, se verificou que um repertório maior de habilidades sociais tende a ser acessado em anos escolares mais avançados e parecem facilitar o desempenho em diferentes áreas de desempenho igualmente. Os resultados

Mailing address: R. Leonita Faber Ladeira, 762, Jd. Estádio, Jundiaí, SP, Brasil 13202-010. E-mail: d bartholomeu@yahoo.com.br, montieljm@hotmail.com, projeto_neuropsicologia@yahoo.com.br and silvamarjorie@yahoo.com.br 
apresentam consonância com a literatura, indicando a necessidade de se ampliar as informações acerca do repertório social em crianças com diferentes desempenhos escolares. Neste sentido, pode-se aferir que as condutas se associam às dificuldades específicas em escrita, leitura e matemática e, que o curso destas associações varia em razão do sexo e idade. Além disso, se verificou a importância da avaliação e consideração de estudos sobre as habilidades sociais, dadas as implicações educacionais associadas.

Palavras-chave: Avaliação escolar, desempenho escolar, déficits em habilidades sociais.

\section{Habilidades Sociales y Rendimiento Escolar en Portugués y Matemáticas en los Estudiantes de Enseñanza Primaria}

\section{Resumen}

En el presente trabajo, existe la hipótesis de una asociación entre las habilidades sociales y el rendimiento en la escritura y las matemáticas. Así como las habilidades de conversación y el ingenio sociales se asociaron con el rendimiento académico en las dos áreas en las niñas, mientras que la asertividad se asoció más con el rendimiento en los niños. Por lo tanto, hemos tratado de examinar la relación entre las habilidades sociales y el rendimiento académico en diferentes años escolares y género, con el objetivo de proporcionar evidencia de validez para uso de la Prueba de Habilidades Sociales para Niños en situación escolar (THAS-C). Este estudio evaluó 196 niños de la escuela primaria de dos escuelas en el estado de São Paulo, con edades que varían desde los 8 a los 10 años, 52\% mujeres. Para evaluar a los participantes, se utilizó La Prueba de Habilidades Sociales para niños en situación escolar y la Prueba de Escritura de rendimiento, Lectura y Matemáticas. Entre los resultados, se encontró que el aumento de las habilidades sociales tiende a ocurrir más en años escolares más avanzados y parecen facilitar el desempeño igualmente en diferentes áreas. Los resultados indican la necesidad de ampliar las informaciones acerca de las habilidades sociales de los niños con diferentes problemas de aprendizaje. En eso sentido, podríamos inferir que las conductas se asocian a dificultades específicas en la lectura, escritura y matemáticas y que el curso de estas asociaciones varía en función del sexo y la edad. Además, es importante que las habilidades sociales sean estudiadas en esta población, dada las implicadas educacionales asociadas.

Palabras clave: Evaluación escolar, rendimiento académico, déficits de las habilidades sociales.

Based on the notes provided by Almeida et al. (1995), school failure is a recurrent phenomenon in the Brazilian educational history, thus it becomes a chronic and permanent challenge for psychologists, pedagogues and related professionals, since it is originated from a group of factors of personal, family, emotional, pedagogical, and social order. Among them, social interactions are understood as educative, as they represent conditions to acquire cognitive concepts and strategies that affect social and school development (Coll \& Sole, 1995; Del Prette \& Del Prette, 1997). Child's pleasant social interactions with friends and teachers require a proper group of social skills from all the involved parties (i.e. from different classes of social behaviors to appropriately deal with the demands of interpersonal situations; Del Prette \& Del Prette, 2001, 2003; Del Prette $\&$ Del Prette, 2005). Efforts to investigate the underlying factors or those associated with academic difficulties in reading, writing and math are increasing. Hence, social skills difficulties are defined as deficits of acquisition or of proper performance in the interaction demands of situation and culture and, therefore, they interfere in the quality of these relations (Del Prette \& Del Prette, 2005; Gresham, 2009; Malecki \& Elliott, 2002; McClelland, Morrison, \& Holmes, 2000).

The psychosocial factors associated with school performance include the concepts of self- 
effectiveness, learning motivation, beliefs (Medeiros, Loureiro, Linhares, \& Marturano, 2000, 2003), affective aspects (Loureiro, Marturano, Linhares, Machado, \& Silva, 1994), school factors, learning environment, instruction type and intensity, teacher characteristics and resources in the family environment, such as the ability to deal with the challenges of school integration, parental involvement with child schooling, presence of resources in the physical environment, educational practices, and discipline (Marturano, 1999). In addition, socioeconomic variables (Leybaert, Alégria, Deltour, \& Skinkel, 1997; Yavas \& Haase, 1988), sociocultural environment (Witter, 1996) and sociolinguistic variables (Tasca, 2002), such as school level, socioeconomic class and specific instruction on the writing rules, are associated with children's performance in reading and writing.

According to Gardinal and Marturano (2007), the evaluated quality (positive or negative) of the social relations established between children in the classroom at Child Education might affect their learning. Positive relations in the classroom are associated with good performance in reading and writing. Research in this area (Bartholomeu et al., 2009; Del Prette \& Del Prette, 2003; Gresham, 2009) has showed that children with low school performance present interpersonal characteristics, which include, among other aspects: a tendency of being more aggressive, presenting more negative interactions with their partners, showing more personality problems, less task-based behaviors, and presenting a less elaborated group of proper and socially desirable interpersonal behaviors compared to children without these difficulties (Marturano, Linhares, \& Parreira, 1993; Pinheiro, Haase, Del Prette, Amarante, \& Del Prette, 2006). In the teachers' evaluation (Maluf \& Bardelli, 1991), students with school difficulties are considered restless, belligerent, reserved and without initiative, with deficits in the abilities of making and keeping friends, ending a conversation, playing with other kids, and interacting with friends.

Different studies focused on the evaluation by friends also showed that students with lower school performance are less accepted than their friends without such difficulties (Bartholomeu, Montiel, \& Pessotto, 2011; Stone \& La Greca, 1990; Vaughn \& Hogan, 1990; Vaughn, McIntosh, \& Spencer-Rowe, 1991). According to the notes of Gresham, Lane, MacMillan, Bocian and Ward (2000), and Kavale and Forness (1996) mention classmates as an important source of information on the social group of children with behavior problems and school difficulties. Molina and Del Prette (2006) and Renk and Phares (2004) consider parents as qualified informers of these children's socioemotional characteristics. However, there are some authors who mention contexts in which children with school difficulties might not present deficiencies in social skills (Elliott, Pring, \& Bunning, 2002; Gresham, 2009; Swanson \& Malone, 1992). Gresham (1992) suggests three hypotheses that might guide studies, between social skills and school difficulties: the causal hypothesis, in which deficits in social skills and learning inability would be attributed to a central nervous system dysfunction; the hypothesis of concomitance between deficiency in social skills and learning difficulties; and correlational hypothesis (i.e. a tendency of some students with higher social skills scores in presenting better school performance).

Based on some studies (Kavale \& Forness, 1996; Medeiros \& Loureiro, 2004; Swanson \& Malone, 1992), detailed evaluation and monitoring of interpersonal and school difficulties, previously presented by children, might be important for planning pedagogical and effective strategies. Some authors usually consider the deficits in social skills as a risk factor for academic accomplishment and socioemotional development (Del Prette \& Del Prette, 2005; Gresham, 2009), which can be worsened in adolescence and adulthood (Caprara, Barbaranelli, Pastorelli, Bandura, \& Zimbardo, 2000; DiPerna \& Elliott, 2000; Malecki \& Elliott, 2002). The evaluation of children's social skills should, as possible, be conducted through a multimodal outlining (i.e. based on different procedures - interviews, inventories, observation -, instruments and informers - parents, teachers, students and classmates; Del Prette \& Del Prette, 2009; Del 
Prette \& Del Prette, 2005; Gresham \& Elliott, 2008).

In the national and international literature, generally, social skills are pointed out as important indicators of school performance, and thus they are highly correlated as positive (for example, Feitosa, Del Prette, \& Del Prette, 2012 and Feitosa, Del Prette, Del Prette, \& Loureiro, 2011). Some authors state that social skills might have a high relation with school performance in the critical years of transition from high school to college (Comedis, 2014). However, the direction and processes implicated in the association between social skills and school performance are not very clear if we consider the various school levels and genders, thus showing the need of more studies in the area, mainly regarding these variables (Bloom, Karagiannakis, Toste, Heath, \& Konstantinopoulos, 2007). Furthermore, the extensive and systematic literature review of Gifford-Smith and Brownell (2003) indicated that the majority of studies involving social skills and acceptation and rejection among colleagues are concentrated on children and increasingly focused on rejection, with a smaller amount of studies on acceptance. They also emphasize that most of the studies on sociometry were conducted until the 90 s, with a smaller amount of studies after such date.

We must give emphasis to some studies conducted with Elementary School students. Del Prette and Del Prette (2003) indicated that 20 to $42 \%$ of children with reading, writing and math difficulties presented some indications of the following behavior problems. They get easily distracted; argue with others; discuss with others; seem restless or constantly moving their bodies; low self-esteem; interrupt other people's conversation; disturb the ongoing activities; get easily angry; threaten or intimidate other people; answer back when adults correct them, and act impulsively. As seen, such notes happen more frequently due to externalizing behavior problems (Del Prette \& Del Prette, 2003; Kavale \& Forness, 1996). The high frequency of internalizing behaviors might compromise friendships and important school-learning behaviors, such as asking questions, taking doubts, and asking colleagues and teachers for help. The high frequency of externalizing behaviors also compromises the quality of children's relations with their teachers and pairs, as well as school adequacy. These results are in accordance with previous research (Gresham, Lane, McMillan, \& Bocian, 1999; Gresham et al., 2000) that point out low school adequacy by children with comorbidity of school relegation and behavior problems.

According to data obtained by Bandeira Rocha, Pires, Del Prette and Del Prette (2006) from Elementary School students, children from private schools and with higher socioeconomic level have more raised academic competence levels. Besides this factor, we can also mention that children's social skills are directly associated with their level of competences and disapprovals. Montiel, Bartholomeu, Lima, Guidetti, and Machado (2011) listed children's difficulties in writing and social skills and revealed that only the civility and altruism factor was negatively associated with writing difficulties, thus suggesting that the more children are altruists, the less they tend to make writing mistakes.

As noticed, there are some indications in the literature regarding the relations between school performance and social skills. Therewith, new instruments assessing social skills should also show their associations with school performance, which are an evidence of validity; since, as stated by Messick (2000), the validity of an instrument is reported based on the representation and relations of theoretical constructs in the instruments. Thus, this study aimed at establishing the relations between children's social skills and reading, writing and math performance, seeking to provide evidence of validity to the Test of Social Skills in Children and Adolescents in school situation (THAS-C). It is assumed that scores of standardized measure of reading, writing and math performance will be associated with THAS-C results in the different studied series and genders, since showing the associations of these constructs in different subgroups (Anastasi \& Urbina, 2000) is relevant. Furthermore, social skills tend to be differently associated in the 
indicators of group cohesion in the varied school years and genders. Nevertheless, group cohesion is also usually associated with good school performance, reporting the hypothesis that the relation between social skills and writing, reading and math performance would also, therefore, be different due to such subgroups (Bloom et al., 2007; Comedis, 2014; GiffordSmith \& Brownell, 2003).

It is expected that civility and altruism are positively associated with writing, reading and math performance, especially in writing, since other literature studies have already showed these relations (Montiel et al., 2011). In addition, it is assumed that conversational skills and social resourcefulness will be morepositively associated with school performance in the three areas. This is due to the fact that deficits in making and keeping friends, ending a conversation, playing and interacting with friends are characteristics of children with learning difficulties. Furthermore, such deficiencies tend to compromise friendships and important school-learning behaviors, such as asking questions, taking doubts and asking friends and teachers for help (Del Prette \& Del Prette, 2003; Del Prette \& Del Prette, 2005; Gresham, 2009; Gresham et al., 1999; Gresham et al., 2000; Pinheiro et al., 2006).

\section{Method}

\section{Participants}

The study included 196 children from two Elementary Schools of São Paulo countryside, one private $(N=72)$ and one state $(N=124)$ institution. The mean socioeconomic level of the schools was two salaries (around BRL 1600.00 per month). The collection took place in the end of 2010 and children were aged 8 years to 4 months and 10 years and seven months, with mean age of 9 years and five months and standard deviation of $.834 ; 52 \%$ of the children were female, studying in the $4^{\text {th }}(N=88)$ and $5^{\text {th }}$ school years $(N=83)$.

\section{Instruments}

Test of Social Skills in Children and Adolescents in School Situation (THAS-C;
Bartholomeu, Silva, \& Montiel, 2014). This instrument was developed in order to measure the social skills that were specifically directed to children's school context. The test is comprised by 23 items were presented to the participant so that he/she could answer them regarding the frequency on which the child behaves as described in the items with answers separated in a three-point Likert scale. The categories were Never, Sometimes and Always, and each answer received points from 1 to 3 , respectively, in the instrument correction, in which they were summed up. Some items are scored oppositely, since the socially skilled behavior is defined contrarily to what the sentence proposes. Hierarchizing the difficulty of items by identifying which behaviors are easier to be presented in the social interaction enables to plan interventions for people with low social skillfulness. Firstly, we should present the easiest behaviors a person can make, and then we should present the more complex behaviors, thus allowing an accurate evaluation of the child's behavioral repertoire, enabling a behavioral arrangement.

The results of the preliminary analysis made by the main components and Varimax rotation (with 257 subjects) suggested the structure of three more evident factors that explained $34.17 \%$ of variance. The first factor was named Civility and Altruism and presented a Cronbach alpha index of .87; the second one, Resourcefulness and self-control in social interaction, obtained a .84 coefficient; and the third one, Assertiveness with encouragement evidenced a .60 alpha. This structure was replicated in a later study (reported in the mentioned manual) with 1,381 subjects.

The first dimension, Civility and Altruism, comprises skills like thanking compliments, apologizing, helping friends, complimenting them, expressing positive feelings to the pairs, being polite when reporting an opinion. In the second factor, Resourcefulness and self-control in social interaction, its indicators should be inverted to show such aspects. The proposed situations suggest negative contexts in which the child is exposed to new social behaviors, which are unknown or that might cause constraint like receiving criticism, talking to an entire class, 
ending a conversation, introducing him/herself to a group of unfamiliar people or asking them something. At last, the third dimension received the denomination of Assertiveness with encouragement. The proposed skills include showing unpleasantness, defending their rights and opinions, resisting to group pressure, stating their self-esteem on the risk of an undesirable reaction by the listener. The Rasch analysis applied to these items identified their level of difficulty, enabling the observation of indicators that assess median social skills, although the level of item difficulty increases from one factor to the other. In addition, the adequacy of the remaining items from the Rasch scale showed that any of them were out of the acceptable limits regarding Rasch model.

Writing, Reading and Math Performance Test for Elementary School (Silva, Montiel, Pires, \& Bartholomeu, 2010). The Writing, Reading and Math Performance Test for Elementary School was also used. It was developed in order to assess the ability of reading and interpreting small texts; writing words that were dictated or from figures and the execution of arithmetical operations given in expression forms and through problem resolution, and thus indicate the possible lacks in learning; and which areas could need more school monitoring. The test was firstly created to evaluate the second to ninth year of Elementary School, since it comprises items with basic and more complex skills, divided into easy, medium and hard. This instrument presents accuracy indices by Kuder Richardson (sample of 251 children), varying between .85 and .92 to its factors (dictation, designation, problems, made with proposed calculations by writing, and calculations, in which only the equations for solution were given) that showed one dimension through Rasch model (each of them separately). The factor analysis through Testfact program indicated the existence of these four factors that together explain $45 \%$ of variance and the two-factor analysis showed two factors, one associated with mathematics and the other with reading and writing. It is worth mentioning these results are presented in a technical report of this instrument, which is included in its preliminary psychometric analyses and its manual is being developed.

\section{Procedure}

The instruments were used together and applied in classrooms with students whose parents had previously provided authorization by signing the free informed consent (under number in the Ethics Committee 424-2010). There was no early selection of students and all students whose parents had provided authorization participated in the sample, thus it was a convenience sample. Disabled children did not participate in the research, since we aimed at obtaining a sample of children without preestablished diagnosis. The children were initially explained that it was a research and how to answer each instrument. An investigator read the questions one by one, waiting for the answer before following to collection, and the THAS-C was firstly applied. Children who did not want to proceed were free to do it; thus, they were released from the situation.

\section{Results and Discussion}

The correlation coefficients between school performance in reading, writing and mathematics evaluated by using the test of social skills and performance, which were assessed in the general THAS-C and separated by subgroups (age, gender and school year, respectively), are in Tables $1,2,3$ and 4 .

We found through these data that the performance in writing by dictation and by figures is moderately and positively associated with altruism and weakly and positively associated with general social skills. This facilitates the following interpretation: with the increase of skills related to Civility and Altruism, there is a tendency of a corresponding increase in writing performance, both by dictation and by figures. Montiel et al. (2011) had already identified this finding. These authors showed the same association by using another assessment instrument of writing learning problems (ADAPE). Hence, apparently, skills related to altruism and civility are associated with a better learning of writing. 
Specifically, the assertiveness factor was positively associated, however it was weak, with the writing performance by figures and moderately in the resolution of arithmetical problems, which shows a tendency that the most assertive children can more easily have a good performance, especially in the arithmetical aspect. Such aspect confirms the results of Del Prette and Del Prette (2003), Gresham et al. (1999), Gresham et al. (2000), in which they point out a higher incidence of externalizing behaviors like asking for help and taking doubts, associated with assertiveness and good school performance. It is worth noting that in the arithmetical questions demanding more time, strategies and functions like memory, assertiveness and ability of asking friends for help can be understood as behaviors that facilitate the performance in this kind of task. Thus, children that usually express themselves, report doubts and ask more easily for help tend to solve their tasks better. This fact opens space for new research.

The relation between social skills and performance was also tested separated by school year. Table 2 presents Pearson correlation coefficients between performance aspects and THAS-C separated by school year. This analysis was done after considering that the relations between social skills and group cohesion are distinct in different phases of the schooling process, therefore differences in the associations with school performance in varied phases of the educational period are also expected (GiffordSmith \& Brownell, 2003).

It is seen that performance in the fourth year, both in writing by dictation and by figures, is positive and significantly associated with altruism and general social skills. Thus, the relations found with the whole sample remained in fourth-year students, with the exception of associations between writing by figures and assertiveness that did not remain in this year. In the $5^{\text {th }}$ year, positive and significant associations different from zero between the performance in writing by dictation and resolution of arithmetical operations with the skills of altruism, assertiveness and general social skills were seen. It is interesting to notice that larger social skills were associated with good academic performance both in writing and mathematics in this school year. Thus, assertiveness was associated with good performance in writing by dictation and the conversational skills with writing by figures. Also with regard to mathematics, civility and altruism were also associated with good performance on problem solution.

Table 1

Pearson Correlation Coefficient between Aspects of Performance and of THAS-C

\begin{tabular}{|c|c|c|c|c|c|}
\hline Performance aspects & & Altruism & $\begin{array}{l}\text { Conversational skill and } \\
\text { social resourcefulness }\end{array}$ & Assertiveness & $\begin{array}{c}\text { General } \\
\text { social skill }\end{array}$ \\
\hline \multirow[t]{2}{*}{ Dictation writing } & $r$ & $.40^{*}$ & -.14 & .19 & $.31 *$ \\
\hline & $p$ & .01 & .17 & .06 & .01 \\
\hline \multirow[t]{2}{*}{ Figure writing } & $r$ & $.38^{*}$ & -.12 & $.22 *$ & $.31 *$ \\
\hline & $p$ & .01 & .28 & .04 & .01 \\
\hline \multirow[t]{2}{*}{ Numerical order } & $r$ & .09 & -.09 & -.01 & .02 \\
\hline & $p$ & .39 & .38 & .94 & .83 \\
\hline \multirow[t]{2}{*}{ Arithmetical operations } & $r$ & .34 & .07 & .11 & .36 \\
\hline & $p$ & .07 & .71 & .57 & .06 \\
\hline \multirow[t]{2}{*}{ Arithmetical problems } & $r$ & .17 & -.08 & $.44^{*}$ & .23 \\
\hline & $p$ & .34 & .64 & .01 & .20 \\
\hline
\end{tabular}

Note. ${ }^{*}$ Significant correlation. 
Table 2

Pearson Correlation Coefficient between Aspects of Performance and of THAS-C Separated by School Year

\begin{tabular}{|c|c|c|c|c|c|c|}
\hline Year & Performance aspects & & Altruism & $\begin{array}{l}\text { Conversational skill and } \\
\text { social resourcefulness }\end{array}$ & Assertiveness & $\begin{array}{c}\text { General } \\
\text { social skill }\end{array}$ \\
\hline \multirow[t]{10}{*}{4} & Dictation writing & $r$ & $.42 *$ & -.10 & .15 & $.34 *$ \\
\hline & & $p$ & .01 & .51 & .34 & .02 \\
\hline & Figure writing & $r$ & $.45^{*}$ & -.04 & .16 & $.40^{*}$ \\
\hline & & $p$ & .01 & .82 & .30 & .01 \\
\hline & Numerical order & $r$ & .26 & -.11 & -.03 & .14 \\
\hline & & $p$ & .07 & .46 & .82 & .34 \\
\hline & Arithmetical operations & $r$ & .42 & .09 & -.10 & .41 \\
\hline & & $p$ & .14 & .77 & .75 & .15 \\
\hline & Arithmetical problems & $r$ & .15 & .31 & $.61^{*}$ & $.56^{*}$ \\
\hline & & $p$ & .62 & .30 & .03 & .05 \\
\hline \multirow[t]{10}{*}{5} & Dictation writing & $r$ & $.41^{*}$ & -.19 & $.35^{*}$ & $.35^{*}$ \\
\hline & & $p$ & .01 & .22 & .02 & .02 \\
\hline & Figure writing & $r$ & $.33^{*}$ & $-.34 *$ & $.41 *$ & .19 \\
\hline & & $p$ & .04 & .04 & .01 & .24 \\
\hline & Numerical order & $r$ & -.04 & -.09 & .20 & -.03 \\
\hline & & $p$ & .79 & .56 & .19 & .87 \\
\hline & Arithmetical operations & $r$ & $.77^{*}$ & -.29 & $.68^{*}$ & $.64^{*}$ \\
\hline & & $p$ & .01 & .38 & .02 & .03 \\
\hline & Arithmetical problems & $r$ & .40 & -.23 & .46 & .36 \\
\hline & & $p$ & .11 & .35 & .06 & .15 \\
\hline
\end{tabular}

Note. * Significant correlation.

This fact suggests that a larger amount of social skills tends to be used in older ages, which seems to similarly facilitate the performance in different academic areas. On one hand, this might happen due to the larger variability both of social skills groups and of performance in writing and mathematics in these school years. On the other hand, it strengthens the evidence that a larger group of social skills tends to facilitate learning in different areas, as suggested in other research with this regard (Bartholomeu et al., 2009; Bartholomeu, Montiel, et al., 2011; Del Prette \& Del Prette, 2003; Montiel et al., 2011; Stone \& La Greca, 1990; Vaughn \& Hogan, 1990; Vaughn et al., 1991).
As Gresham (1992) recommends, there are positive correlations between good social and school performances, but not all children with some kind of group might present a difficulty, thus it is noteworthy the analysis of the functionality of this relation between these two constructs. In other words, these deficiencies might be due to other difficulties that the child might be living and are indicators of problems in the child's socioemotional development, which tend to get worse during adolescence and adulthood if they are not taken care. Therefore, when correlations between social skills and school performance are low, other factors might affect this relation, like socioemotional 
problems, which must be further investigated in cases of learning difficulties. Hence, literature points out that social skills tend to be protection factors for the academic accomplishment and good socioemotional development, depending on how such behaviors are used (i.e. of the social competence; Del Prette \& Del Prette, 2005; Gresham, 2009).

The present study also showed low coefficients between these measurements. Thus, the suggestions made by Del Prette and Del Prette (2005) and Gresham (2009) regarding the fact that other socioemotional factors might affect the functionality of this relation between social skills and school performance, is a plausible explanation, therefore it requires new investigations. Another analyzed possibility were the differences in the standard of associations between these variables by gender, since varied social behaviors are usually differently associated with group cohesion in several groups (GiffordSmith \& Brownell, 2003). Thus, the possible associations between these two constructs are further analyzed by separating the participants by gender. Results are presented in Table 3, in which Pearson correlation coefficients are presented between performance and THAS-C aspects separated by gender.

Table 3

Pearson Correlation Coefficient between Aspects of Performance and of THAS-C Separated by Gender

\begin{tabular}{|c|c|c|c|c|c|c|}
\hline Gender & Performance aspects & & $\begin{array}{c}\text { Civility and } \\
\text { Altruism }\end{array}$ & $\begin{array}{l}\text { Conversational } \\
\text { skill and social } \\
\text { resourcefulness }\end{array}$ & Assertiveness & $\begin{array}{c}\text { General } \\
\text { social skill }\end{array}$ \\
\hline \multirow[t]{10}{*}{ Male } & Dictation writing & $r$ & $.48^{*}$ & -.04 & $.36^{*}$ & $.49^{*}$ \\
\hline & & $p$ & .01 & .81 & .02 & .01 \\
\hline & Figure writing & $r$ & $.39 *$ & -.07 & $.39 *$ & $.41 *$ \\
\hline & & $p$ & .01 & .66 & .01 & .01 \\
\hline & Numerical order & $r$ & .19 & -.28 & .29 & .11 \\
\hline & & $p$ & .21 & .07 & .05 & .46 \\
\hline & Arithmetical operations & $r$ & $.60 *$ & .03 & $.76^{*}$ & $.64^{*}$ \\
\hline & & $p$ & .04 & .93 & .01 & .03 \\
\hline & Arithmetical problems & $r$ & .45 & .31 & .40 & $.54^{*}$ \\
\hline & & $p$ & .08 & .24 & .13 & .03 \\
\hline \multirow[t]{10}{*}{ Female } & Dictation writing & $r$ & .27 & -.21 & .05 & .11 \\
\hline & & $p$ & .06 & .15 & .71 & .44 \\
\hline & Figure writing & $r$ & $.35^{*}$ & -.14 & .07 & .22 \\
\hline & & $p$ & .02 & .37 & .66 & .15 \\
\hline & Numerical order & $r$ & .04 & -.01 & -.25 & -.06 \\
\hline & & $p$ & .81 & .93 & .08 & .69 \\
\hline & Arithmetical operations & $r$ & .26 & .05 & -.22 & .17 \\
\hline & & $p$ & .34 & .85 & .41 & .53 \\
\hline & Arithmetical problems & $r$ & -.02 & -.38 & .45 & -.11 \\
\hline & & $p$ & .95 & .13 & .07 & .67 \\
\hline
\end{tabular}

Note. * Significant correlation. 
These results show that the largest positive and significant associations are seen more separately to male participants. Therefore, the higher the performance in writing by words, figures and mathematical operations is, the higher the tendency of an increase in the Altruism, Assertiveness and general social skills. Of the initially presumed hypotheses regarding the relations between these variables by gender, only some of them were confirmed. Indeed, in the male gender, assertiveness was associated with performance both in writing and in mathematics, in addition to civility and altruism. However, in the female gender, only civility and altruism were associated with performance in writing by figures, which had not been assumed.

Based on the analyzes, we verified which of the social skills better explained the performance in each evaluated aspect of writing, reading and mathematics. In order to do so, we used the lineal regression analysis with the backward method of variables entry, in which the dependent variables included the school performance factors and the social skills comprised the independent ones. The collinearity diagnosis showed no problems regarding this subject (Tolerance and variance inflation factor [VIF] indices within the expected parameters).

Table 4 presents the regression coefficients for the models that presented statistical significance. By means of these data, the general score of social skills significantly predicted the performance in dictation and designation tests, while the assertiveness factor explained the performance in mathematics problems. All the coefficients were positive or low to moderate. It suggest that the contribution of these factors of social skills, although not so large to each kind of activity (the reason for the low variance), was significant. These tendencies suggest that the increase of social skills corresponds to an increase in the performance of dictation (writing) and designation (reading), and the increase of assertiveness is followed by the increase of right answers in mathematical problems.

Table 4

Regression Analysis between Aspects of Performance and of THAS-C

\begin{tabular}{|c|c|c|c|c|c|c|}
\hline \multirow[t]{2}{*}{ Model } & & \multicolumn{2}{|c|}{ ANOVA } & \multirow{2}{*}{$\begin{array}{c}\begin{array}{c}\text { Standardized } \\
\text { coefficients }\end{array} \\
\text { Beta }\end{array}$} & \multirow[t]{2}{*}{$t$} & \multirow[t]{2}{*}{$p$} \\
\hline & & $F$ & $p$ & & & \\
\hline \multirow[t]{2}{*}{3 Designation } & (Constant) & 3.80 & .05 & & 2.39 & .02 \\
\hline & General social skill & & & .21 & 1.95 & .05 \\
\hline \multirow[t]{2}{*}{3 Problems } & (Constant) & 4.70 & .04 & & -0.21 & .83 \\
\hline & Assertiveness & & & .36 & 2.17 & .04 \\
\hline \multirow[t]{3}{*}{2 Dictation } & (Constant) & 5.57 & .01 & & 1.73 & .09 \\
\hline & Conversational and social resourcefulness & & & -.17 & -1.72 & .09 \\
\hline & General social skill & & & .27 & 2.68 & .01 \\
\hline
\end{tabular}

Only the measure of general social skill remained in the explanative model of performance in the dictation and designation. Hence, a larger amount of children's social behaviors is needed so that the performance in both areas covariates. However, in the mathematical problems, the increase of assertiveness might be suggested as a variable presenting some ef- fect on its improvement. Then, intervention in social skills aimed at improving children's school performance could take some different paths and focuses due to the kind of specific difficulty presented by the child.

The study of Bartholomeu et al. (2014), which analyzed the THAS internal structure, suggest that the levels of difficulties of social be- 
haviors in this test might be used as references for planning training in social skills. Thus, improvement in writing and reading performance could be thought as a training that begins in the easiest elements (altruism and civility) until the hardest ones (assertiveness). On the other hand, in math, the hardest abilities to be trained (as the authors suggest) should be the focus of intervention. Such aspect requires further investigations on the intervention in these two scopes. We should consider that boys usually present more school difficulties than girls, and these differences in the associations of social skills and school performance had already been identified in other studies, such as Bandeira et al. (2006) and Montiel et al. (2011) studies. In fact, a larger group of social skills seems to be favorable to performance, especially in boys from the I Elementary School Education. In girls, some aspects (like altruism) are normally associated with school performance.

Surely, emotional and social problems usually affect more the school performance in boys than in girls, as seen in other studies, thus this result was expected (Bartholomeu, Sisto, \& Rueda, 2006). Nevertheless, these aspects should be considered when planning interventions regarding socioemotional aspects of children with learning difficulties. Indeed, the present article showed that social skills tend to be more associated with school performance in boys and children (from both genders) of more advanced school years (fifth grade - II part of Elementary School). New research could try to insert and extend the social group of younger children to verify if these skills, when earlier learned, tend to facilitate the school performance in the first years, based on the assumption of Gresham (1992) and Gresham et al. (1999) that social skills would be more protective regarding school performance. This would demand studies with experimental outlining and more control, besides other kinds of information collection on the child's social repertoire like parents and teachers (Gresham, 1992; Gresham, et al., 2000; Kavale \& Forness, 1996).

\section{Final Considerations}

In general, these results are in agreement with the suggestions of Molina and Del Prette (2006) and Renk and Phares (2004), which indicated the need of increasing the amount of information about children's social repertoire in children with school difficulties. Hence, behaviors associated with specific performances in writing, reading and mathematics were indicated, in addition to the course of these associations varying due to gender and age, which also found basis in other studies like of Bandeira et al. (2006) and, more recently, of Montiel et al. (2011).

Even though some correlations had been low, these results could be reflected in terms of group cohesion, since social skills consist in some of the characteristics that ensure a better group cohesion mainly based on the decrease of social rejection (Bartholomeu, Carvalho, Silva, Miguel, \& Machado, 2011; Bartholomeu, Montiel, et al., 2011; Gifford-Smith \& Brownell, 2003). Furthermore, studies have showed that a good group cohesion usually facilitates school performance (Gifford-Smith \& Brownell, 2003). Then, it would be worth investigating if correlations between social skills and school performance are not mediated by group cohesion or, in other terms, by acceptance and rejection in group. This fact invites new investigations on the theme.

Work limitations include the decreased amount of children in some measurements, which directly influenced on the level of significance of the found correlations. Thus, some moderate coefficients did not achieve statistical significance and should be considered as a representation of the studied sample, but not useful for generalizations, because they do not present nomothetic representation. Then, studies with larger samples would be interesting possibilities for the continuity of this work. In addition, even though the correlational approach is a possibility to investigate the studied constructs (as Gresham, 1992, suggests), more controlled studies are needed with the aim of establishing a different impact of each kind of social skill for each spe- 
cific school problem. The present study presents a brief outline (based on measurement correlation) of the possibilities of relations between social skills and school performance, and also points out the importance that the use of skillful social behaviors might mean social competence, to only then be reported in possible school performance improvements.

Briefly, civility and altruism seemed to be more associated with writing, while assertiveness seemed more associated with mathematic performance. These relations are increased and extended in more advanced years and in the male gender, therefore indicating specific points of intervention in social skills with the aim of academic improvement. Studies with this kind of intervention are equally necessary. In general, the associations frequently seen in literature between school performance and social skills were reaffirmed in this study with THAS-C. Therefore, this is an evidence of validity to this test, since the expected relations of this evaluated construct by such test remained in this measure (evaluation convergence). Other evidence of validity could also be analyzed with regard to the relations with other variables, such as the sociometric test and other measures of social skills like the Inventário Multimídia de Habilidades Sociais para Crianças (IMHSC) -Del Prette, which also show the need of new research.

With regard specifically to reading, mathematics and writing, studies relating behavioral problems and social interactions and school performance in these areas show that scientific knowledge acquired in a formal environment of learning will only be effective and productive if it is healthy and pleasant to the student. There is for sure an intense relation between school environment and learning problems, whatsoever. Thus, the work of trained and skilled professionals to pedagogical, psychopedagogical and psychological support should be present. New studies should be conducted with longitudinal monitoring in order to follow the effect of variables in several school years. It would also be interesting to recommend an experimental investigation, in which a training on social skills would be applied to children with low school performance, to then verify possible improvements in these aspects.

\section{References}

Almeida, S. F. C., Rabelo, L. de M., Cabral, V. S., Moura, E. R. de O., Barreto, M. de S. F., \& Barbosa, H. (1995). Concepções e práticas de psicólogos escolares acerca das dificuldades de aprendizagem. Psicologia: Teoria e Pesquisa, 11(2), 117-134.

Anastasi, A., \& Urbina, S. (2000). Testagem psicológica $\left(7^{\text {th }}\right.$ ed.). Porto Alegre, RS: ArtMed.

Bandeira, M., Rocha, S. S., Pires, L. G., Del Prette, Z. A. P., \& Del Prette, A. (2006). Competência acadêmica de crianças no Ensino Fundamental: Características sociodemográficas e relação com habilidades sociais. Interação em Psicologia, 10(1), 53-62.

Bartholomeu, D., Bartholomeu, L. L., Machado, A. A., Cozza, H. F. P., Berberian, A. A., \& Montiel, J. M. (2009). Dificuldades de aprendizagem, personalidade, emoções e características psicossociais de crianças: Revisando a literatura e sugerindo modelos. In J. M. Montiel \& F. C. Capovilla (Eds.), Atualização em transtornos de aprendizagem (pp. 355-382). São Paulo, SP: Artes Médicas.

Bartholomeu, D., Carvalho, L. F., Silva, M. C. R., Miguel, F. K., \& Machado, A. A. (2011). Aceitação e rejeição entre pares e habilidades sociais em universitários. Estudos de Psicologia (Natal), 16(2), 155-162.

Bartholomeu, D., Montiel, J. M., \& Pessotto, F. (2011). Sociometria e habilidades sociais em alunos do ensino médio. Estudos Interdisciplinares em Psicologia, 2(2), 211-228. doi:10.5433/2236-6407.2011v2n2p211

Bartholomeu, D., Silva, M. C. R., \& Montiel, J. M. (2014). Teste de Habilidades Sociais para Crianças e Adolescentes em Situação Escolar $T H A S-C$. São Paulo, SP: Memnon.

Bartholomeu, D., Sisto, F. F., \& Rueda, F. J. M. (2006). Dificuldades de aprendizagem na escrita e características emocionais de crianças. Psicologia em Estudo, 11(1), 19-22. doi:10.1590/ S1413-73722006000100016

Bloom, E. L., Karagiannakis, A., Toste, J. R., Heath, N. L., \& Konstantinopoulos, E. (2007). Severity of academic achievement and social skills 
deficits. Canadian Journal of Education, 30(3), 911-930

Caprara, G. V., Barbaranelli, C., Pastorelli, C., Bandura, A., \& Zimbardo, P. G. (2000). Prosocial foundations of children's academic achievement. Psychological Science, 11, 302-306. doi:10.1111/1467-9280.00260

Coll, C., \& Sole, I. (1995). A interação professor/aluno no processo de ensino aprendizagem. In $\mathrm{C}$. Coll, J. Palácios, \& A. Marchesi (Eds.), Desenvolvimento psicológico e educação: Necessidades educativas especiais e aprendizagem escolar. Porto Alegre, RS: ArtMed.

Comedis, E. J. (2014). The drole of social skills in the academic performance of De La Salle Araneta University freshmen students: Creating a culture. Paper presented at the De La Salle University Research Congress, Manila, Philippines. Retrieved from http://www.dlsu.edu.ph/ conferences/dlsu_research_congress/2014/_pdf/ proceedings/LCCS-I-002-FT.pdf

Del Prette, A., \& Del Prette, Z. A. P. (1997). Habilidades sociais e construção de conhecimento em contexto escolar. In D. R. Zamignani (Ed.), Sobre comportamento e cognição: A aplicação da analise do comportamento e da terapia cognitivo-comportamental no hospital geral e nos transtornos psiquiátricos (pp. 234-250). Santo André, SP: Arbytes.

Del Prette, A., \& Del Prette, Z. A. P. (2001). Psicologia das relações interpessoais: Vivências para o trabalho em grupo [Psychology of interpersonal relationships: Experiential strategies for working in group settings]. Petrópolis, RJ: Vozes.

Del Prette, A., \& Del Prette, Z. A. P. (2003). Aprendizagem socioemocional na infância e prevenção da violência: Questões conceituais e metodologia da intervenção. In A. Del Prette \& Z. A. P. Del Prette (Eds.), Habilidades sociais, desenvolvimento e aprendizagem (pp. 83-127). Campinas, SP: Alínea.

Del Prette, A., \& Del Prette, Z. A. P. (2009). Componentes não verbais e paralinguísticos das habilidades sociais. In A. Del Prette \& Z. A. P. Del Prette (Eds.), Psicologia das habilidades sociais: Diversidade teórica e suas implicações (pp. 147-186). Petrópolis, RJ: Vozes.

Del Prette, Z. A. P., \& Del Prette, A. (2005). Psicologia das habilidades sociais na infância: Terapia e educação. Petrópolis, RJ: Vozes.
DiPerna, J. C., \& Elliott, S. N. (2000). ACES: The academic competence evaluation scales (ACES K-12). San Antonio, TX: The Psychological Corporation.

Elliott, C., Pring, T., \& Bunning, K. (2002). Social skills training for adolescents with intellectual disabilities: A cautionary note. Journal of Applied Research in Intellectual Disabilities, 15, 91-96. doi:10.1046/j.1360-2322.2001.00091.x

Feitosa, F. B., Del Prette, Z. A. P., \& Del Prette, A. (2012). Social skills and academic achievement: The mediating function of cognitive competence. Temas em Psicologia, 20(1), 61-70.

Feitosa, F. B., Del Prette, Z. A. P., Del Prette, A., \& Loureiro, S. R. (2011). Explorando relações entre o comportamento social e o desempenho acadêmico em crianças. Estudos e Pesquisas em Psicologia, 11, 442-455.

Gardinal, E. C., \& Marturano, E. M. (2007). Meninos e meninas na Educação Infantil: Associação entre comportamento e desempenho. Psicologia em Estudo, 12, 541-551. doi:10.1590/S141373722007000300011

Gifford-Smith, M. E., \& Brownell, C. A. (2003). Childhood peer relationships: Social acceptance, friendships, and peer networks. Journal of School Psychology, 41, 235-284. doi:10.1016/ S0022-4405(03)00048-7

Gresham, F. M. (1992). Social skills and learning disabilities: Causal, concomitant or correlational? School Psychological Review, 21(3), 348-360.

Gresham, F. M. (2009). Análise do comportamento aplicada às habilidades sociais. In Z. A. P. Del Prette \& A. Del Prette (Eds.), Psicologia das habilidades sociais: Diversidade teórica e suas implicações (pp. 17-66). Petrópolis, RJ: Vozes.

Gresham, F. M., \& Elliott, S. N. (2008). Social skills improvement system: Rating scales. Bloomington, MN: Pearson Assessments.

Gresham, F. M., Lane, L. K., McMillan, D. L., \& Bocian, K. M. (1999). Social and academic profiles of externalizing and internalizing groups: Risk factors for emotional and behavioral disorders. Behavioral Disorders, 24(3), 231-245.

Gresham, F. M., Lane, K. L., MacMillan, D. L., Bocian, K., \& Ward, S. (2000). Effects of positive and negative illusory biases: Comparisons across social and academic self-concept domains. Journal of School Psychology, 38, 151-175. doi:10.1016/S0022-4405(99)00042-4 
Kavale, K. A., \& Forness, S. R. (1996). Social skills deficits and learning disabilities: A metaanalisys. Journal of Learning Disabilities, 29(3), 226-237. doi:10.1177/002221949602900301

Leybaert, J., Alégria, J., Deltour, J., \& Skinkel, R. (1997). Aprender a ler: O papel da linguagem, da consciência fonológica e da escola. In $\mathrm{J}$. Grégoire \& B. Piérart (Eds.), Avaliação dos problemas de leitura: Os novos modelos teóricos e suas implicações diagnósticas (pp. 143-166). Porto Alegre, RS: Artes Médicas

Loureiro, S. R., Marturano, E. M., Linhares, M. B. M., Machado, V. L. S., \& Silva, R. A. (1994). Crianças com queixa de dificuldade escolar: Avaliação psicológica através de técnica gráfica. Arquivos Brasileiros de Psicologia Aplicada, 46, 161-182.

Malecki, C. K., \& Elliott, S. N. (2002). Children's social behaviors as predictors of academic achievement: A longitudinal analysis. School Psychology Quarterly, 17(1), 1-23. doi:10.1521/ scpq.17.1.1.19902

Maluf, M. R., \& Bardelli, C. (1991). As causas do fracasso escolar na perspectiva de professoras e alunos de uma escola de primeiro grau. Psicologia: Teoria e Pesquisa, 7(3), 263-271.

Marturano, E. M. (1999). Recursos no ambiente familiar e dificuldades de aprendizagem na escola. Psicologia: Teoria e Pesquisa, 15, 153-162. doi:10.1590/S0102-37721999000200006

Marturano, E. M., Linhares, M. B. M., \& Parreira, V. L. C. (1993). Problemas emocionais e comportamentais associados a dificuldades na aprendizagem escolar. Medicina (Ribeirão Preto), 26(2), $161-175$

McClelland, M. M., Morrison, F. J., \& Holmes, D. L. (2000). Children at risk for early academic problems: The role of learning-related social skills. Early Childhood Research Quarterly, 15, 307-329.

Medeiros, C. P., \& Loureiro, S. R. (2004). Observação clínica do comportamento de crianças com queixa de dificuldade de aprendizagem. In E. M. Marturano, M. B. M. Linhares, \& S. R. Loureiro, Vulnerabilidade e proteção. Indicadores na trajetória do desenvolvimento escolar (pp. $107-$ 136). São Paulo, SP: Casa do Psicólogo

Medeiros, P. C., Loureiro, S. R., Linhares, M. B. M., \& Marturano, E. M. (2000). A auto-eficácia e os aspectos comportamentais de crianças com dificuldade de aprendizagem. Psicologia: Reflexão e Critica, 13, 327-336. doi:10.1590/S010279722000000300002

Medeiros, P. C., Loureiro, S. R., Linhares, M. B. M., \& Marturano, E. M. (2003). O senso de auto-eficácia e o comportamento orientado para aprendizagem em crianças com queixa de dificuldade de aprendizagem. Estudos de Psicologia (Natal), 8, 93-105. doi:10.1590/S1413294X2003000100011

Messick, S. (2000). Consequences of test interpretation and use: The fusion of validity and values in psychological assessment. In R. D. Goffin \& E. Helmes (Eds.), Problems and solutions in human assessment: Honoring Douglas $N$. Jackson at seventy (pp. 3-20). Boston, MA: Kluwer Academic.

Molina, R. C. M., \& Del Prette, Z. A. P. (2006). Funcionalidade da relação entre habilidades sociais e dificuldades de aprendizagem. Psico-USF, 11(1) 53-63. doi:10.1590/S1413-82712006000100007

Montiel, J. M., Bartholomeu, D., Lima, F. F., Guidetti, A. A., \& Machado, A. A. (2011). Dificuldades de aprendizagem na escrita e habilidades sociais em crianças do ensino fundamental. Revista Portuguesa de Dificuldades de Aprendizagem, 1, 23-32.

Pinheiro, M. I. S., Haase, V. G., Del Prette, A., Amarante, C. L. D., \& Del Prette, Z. A. P. (2006). Treinamento de habilidades sociais educativas para pais de crianças com problemas de comportamento. Psicologia: Reflexão e Crítica, 19(3), 407-414. doi:10.1590/S010279722006000300009

Renk, K., \& Phares, V. (2004). Cross-informant ratings of social competence in children and adolescents. Clinical Psychology Review, 24, 239-254. doi:10.1016/j.cpr.2004.01.004

Silva, M. C. R., Montiel, J. M., Pires, S. D., \& Bartholomeu, D. (2010). Teste de desempenho em leitura, escrita e matemática para o ensino Fundamental. Unpublished manuscript, Laboratório de Psicodiagnóstico e Neurociências Cognitivas, Unisal - Centro Universitário Salesiano de São Paulo, Americana, SP, Brazil.

Stone, W. L., \& La Greca, A. M. (1990). The social status of children with LD: A reexamination. Journal of Learning Disabilities, 23, 32-37. doi:10.1177/002221949002300109

Swanson, H. L., \& Malone, S. (1992). Social skills 
and learning disabilities: A meta-analysis of the literature. School Psychology Review, 21(3), 427-443.

Tasca, M. (2002). Interferência da língua falada na escrita das séries iniciais: O papel de fatores linguísticos e sociais. Porto Alegre, RS: Editora Universitária da Pontifícia Universidade Católica do Rio Grande do Sul.

Vaughn, S., \& Hogan, A. (1990). Social competence and learning disabilities: A prospective study. In H. L. Swanson \& B. K. Keogh (Eds.), Learning disabilities: Theoretical and research issues (pp. 175-191). Hillsdale, NJ: Erlbaum.

Vaughn, S., McIntosh, R., \& Spencer-Rowe, J. (1991). Peer rejection is a stubborn thing: Increasing peer acceptance of rejected students with learning disabilities. Learning Disabilities Research \& Practice, 6, 83-88.
Witter, G. P. (1996). Fatores socioculturais e leitura: Estudo da produção arrolada no ASIRR (1989/1994). Estudos de Psicologia (Campinas), 13, 49-56.

Yavas, F., \& Haase, V. G. (1988). Consciência fonêmica em crianças na fase de alfabetização. Letras de Hoje, 23(4), 31-55.

Recebido: $12 / 11 / 2014$

$1^{a}$ revisão: 10/07/2015

$2^{a}$ revisão: 1\%09/2015 Aceite final: 19/11/2015 